THE SKIN SENSES Compiled and Edited by Dan R. Kenshalo. (Pp. xvii +636 ; illustrated. $\$ 26.00$.) Thomas: Springfield, Ill. 1968.

The title of this book belies its total content, for though the bulk of the symposium is devoted to sensory structures in the skin and the way in which they function, the studies extend centrally through the dorsal horn as far as the caudate nucleus. All relevant disciplines are present including electron microscopy, histochemistry, pharmacology, electrophysiology, and psychology and the technology employed ranges from the computer on the one hand to the smoked drum on the other.

It seems, however, that after decades of work on sensation, the basic argument is still the same-namely, specificity versus patterning in the sensory system. The studies of ultrastructure and histochemistry certainly reveal a degree of differentiation of receptors which must surely have functional significance, and electrophysiology bears this out with the recognition of slow and rapid types of adoption. Some of the treatment is highly mathematical and, overall, this is a book for the specialist in this field rather than for the general reader.

There are abundant references, excellent illustrations, and good name and subject indices, the standard of production being high, a fact which is reflected in the price of 26 dollars.

\section{JOHN MARSHALL}

HUMAN NEUROLOGICAL ORGANIZATION By Edward B. Le Winn. (Pp. xv $+227 ; 24$ figures, 3 tables. \$8.50.) Thomas: Springfield, Ill. 1969.

The Rehabilitation Center, Philadelphia, uses a scheme of recording the neural development of children, known as the Doman Delacato Development Profile. This book, 216 pages long, is written to describe, explain, and justify this scheme. The major part of the book, and nearly all of the first 70 pages, have nothing to do with this scheme, however. There is a vague discussion of brains in general, all of which is well known to neurologists and to readers of the Scientific American. A great deal of the book consists of platitudes; all of it is badly written.

\section{P. W. NATHAN}

GARRISON'S HISTORY OF NEUROLOGY By Lawrence C. McHenry Jr. (Pp. Xv + 552; 187 figures. \$14.50.) Thomas: Springfield, Ill. 1969.

Fielding $\mathrm{H}$. Garrison, author of the celebrated Introduction to the History of Medicine later wrote a separate chapter on the history of neurology as part of Charles Dana's Textbook of Nervous Diseases. Garrison himself was dissatisfied with his contribution and it was never reprinted. This chapter, which reviewed the place of neurology in the context of medical history as a whole, was one which Garrison was uniquely qualified to make, but it would in all probability have been forgotten but for the enthusiasm and industry of Dr. McHenry, assistant professor of neurology at Jefferson Medical College. Garrison's text has been revised and expanded, extending now to the earlier part of the 20th century and Dr. McHenry has added chapters on clinical neurology, neurochemistry, neurological examination, and neuropathology. The style of the original has been maintained throughout, although the emphasis in the first part is on ideas, and in the second part, with the exception of the last chapter, on men and their individual contributions. As a result, the later chapters, which necessarily include many more names, tend to read like a neurological Who's Who with short biographical notes and resumé of main contributions. Only with the major figures, such as Charcot and Jackson, does the author allow himself space to do justice to his subjects. The book will undoubtedly be widely appreciated as a work of reference and contains excellent illustrations and full bibliography.

\section{R. W. ROSS RUSSELL}

CENTRAL PAIN: A NeURosurgical SURVEY By Valentino Cassinari and Carlo A. Pagni. (Pp. $x+192 ; 26$ figures.

63s.) Harvard University Press: Cambridge, Mass. (London agents: Oxford University Press).

Central pain syndromes are an uncommon but obtrusive part of medical practice. They come within the experience of every neurologist. For the patient they can be an overwhelming disability; for the doctor an insoluble therapeutic problem. This short monograph on neurosurgical aspects of central pain should be welcomed. After introductory chapters on the traditional central pathways and centres for pain, it surveys the neurosurgical lesions which may cause the central pain syndrome. These findings are then considered in relation to various theories of the origin of the condition. The problem is then surveyed from the other side, so to speak, and the results of surgical treatment are reviewed and again considered in terms of possible pathophysiological mechanisms. The general conclusion is in favour of the abnormal activity of the extralemniscal or multisynaptic sensory system as an essential basis for central pain. This system in its cephalad components is represented by the reticular system and it is changed activity here, whether it be enhanced by release, reduced, or simply altered in pattern, that has important implications in cause and treatment.

The organic background is undoubted, but the authors are perhaps a little too cavalier in their assessment of psychological factors in these syndromes. However they have produced a first-rate monograph which brings together and assesses a mass of previously diffused evidence. The book will be of great interest and value to all those dealing with the problems of central pain and anaesthesia dolorosa. It also provides some valuable facts which must be assimilated in any coherent theory of the physiology of pain.

$$
\text { C. W. M. WHITTY }
$$

OPERATIVE SURGERY: HEAD AND NECK AND LYMPH NODES

2nd edn. Edited by C. Rob and R. Smith. (Pp. xii + 254; illustrated. No price quoted.) Butterworth: London.

This volume contains descriptions of a varied collection of operations on the head and neck. A great many operations conducted in these areas are not described and, presumably, they appear in other volumes. One would have liked to see descriptions of operations for 